\title{
Considerations on the Function and Provenance of the Glass in the Plato von Ustinow Collection
}

\author{
Dominic Ingemark
}

\begin{abstract}
The Russian émigré Plato von Ustinow - who settled in Palestine in 1862 and lived there until 1913 - was a keen collector of antiquities. In contrast to other collectors, however, von Ustinow did not purchase the objects from art-dealers. Instead, he appears to have worked with professional archaeologists, but also bought objects from local inhabitants in Jaffa and Jerusalem. His collection includes a substantial number of glass vessels: primarily blown vessels dating to the first- to sixth-or seventh century CE, i.e. the Roman and Early Byzantine era. The von Ustinow collection is comparatively homogeneous, and most of the objects are likely to stem from a relatively limited geographical area, as it closely resembles material from funerary contexts found in modern-day Israel. The collection includes a number of perfume bottles, small jars and kobl-flasks, objects most probably utilised in the preparation of the deceased before burial.
\end{abstract}

Keywords: Roman glass, Early Byzantine glass, the von Ustinow collection of antiquities, Museum of Cultural History $(\mathrm{MCH})$, University of Oslo $(\mathrm{UiO})$

Glass - once exclusive and expensive - became an inexpensive, indeed cheap, massproduced material in the Roman period. ${ }^{1}$ This was due to two important innovations in the manufacture of glass in the last phase of the Roman Republican Era and the Early Imperial period: making of so-called 'cast' glass (i.e., sagged or slumped glass) ${ }^{2}$

\footnotetext{
${ }^{1}$ A number of literary sources mention how cheap glass was, see for example: Strabo, Geographica, 25; Petronius, Satyricon, 51; see also: Stern 1999, 478. As a result of the low prices, glass to some extent came to replace pottery. For instance, it has been noted by Dan Barag that pottery vessels were a rare feature in funerary contexts dating to the Late Roman period in present-day Israel (1978, 40-41).

${ }^{2}$ Given that this method of manufacture was not nearly as efficient as glass blowing it fell out of use and into oblivion. There has been much debate on the actual manufacturing method for socalled 'cast' glass, which is a misnomer as they in all probability were not cast, but rather manufactured by other methods such as sagging or slumping. Many glass historians support the ideas put forward by Keith Cummings, who preferred the term 'mould-pressing'. He claimed that glass vessels were first made by making a flat disc, which was then sagged or slumped on a mould (1980, 26-29). Rosemarie Lierke proposed a method which involved a device resembling a potter's wheel (see: Lierke 1993, 1996, 1999; Stern 2008, 531-534. Lierke's idea has won less scholarly support; see Ingemark 2014, 29).
} 
and glass blowing. ${ }^{3}$ Archaeological evidence seems to indicate that these innovations took place in the Near East; the oldest known finds of blown glass - misshapen vessels and other debris - are from Old Jerusalem. This material dates to the mid-first century $\mathrm{BCE}$, and represents the first attempts to make vessels with this new manufacturing method. ${ }^{4}$ Although these crafts spread to other parts of the Roman Empire relatively rapidly, this region retained an important position in the manufacture of glass.

Today, collections of Roman glass from the Near East abound in museums all around the world. This is, of course, a reflection of the fact that millions upon millions of glass vessels were at one time manufactured there. The fact that many public and private collections are from this area has another cause, however: they were often the result of excavations, clandestine and semi-legal alike, in a region long plagued by political instability and conflicts. ${ }^{5}$ Consequently, we know next to nothing about the archaeological contexts from which these collections originate, except for the fact that the vessels are intact, which demonstrates that they in all likelihood came from funerary contexts.

Aside from the fact that the glass material in the von Ustinow ${ }^{6}$ Collection has its origin in the Near East, all evidence appears to show that it differs from many other museum collections. Most importantly, the collection is comparatively homogeneous in character, and most of the objects are likely to stem from a relatively restricted geographical area. For instance, Randi Frellumstad argues that the majority of objects came from the vicinity of the town in Palestine where Plato von Ustinow chose to settle: Jaffa (present-day Tel Aviv). ${ }^{7}$ Although several convincing arguments are put forward to support this view, it is the present author's opinion that the geographical area cannot be narrowed down to Jaffa alone. Parts of the collection may have originated from funerary contexts in other parts of Central and Southern Israel, areas in which similar assemblages have been unearthed.

\section{The material}

With the exception of a small number of objects of other date and origin (two ring weights from the Abbasid period and a later bird-shaped flask from the Mamluk period $^{8}$ ), the von Ustinow Collection consists almost entirely of blown vessels from

\footnotetext{
3 Stern 1999, 442-443; 2004, 79-81; 2008, 235.

${ }^{4}$ Israeli 1991, 2005. Israeli \& Katsnelson 2006, 411-460 state that Old Jerusalem was not the location of the glass workshop and reject the earliest evidence for blowing. The contradictions in current discourse show that the material in question is still strongly debated among scholars.

${ }^{5}$ Large-scale robbing of cemeteries has a long history in the Near East, going back to at least the later part of the nineteenth century, when the Ottoman Empire started to crumble (Barag 1981, 73). See also, recently, Tal \& Taxel 2015.

${ }^{6}$ For the sake of simplicity, I use the name that Platon Grigorivtsj Ustinov gained after he became a German citizen, Plato von Ustinow, throughout this paper.

${ }^{7}$ Frellumstad 2007, 48-58.

${ }^{8}$ C40795a, C40795b, C40792. Identifications made by Randi Frellumstad (2007: Appendix A, 35).
} 
the first- to sixth- or seventh centuries CE, the Roman and Early Byzantine era. With few exceptions, all of the vessels and objects were manufactured in natural coloured glass - different shades of green, greenish-yellow and bluish-green - which were common colours of this time period.'

In total, around 80 per cent of the collection is made up of different types of unguent bottles, small jars and cosmetic flasks, vessels which were probably used as containers for scented oils or perfumes, skin emollients, cosmetics and similar substances. The unguent bottles were free-blown and display a great deal of variation in shape, rendering the task of classification, and hence also dating, difficult. Clasina Isings (and others) have made attempts to place these within a typology. ${ }^{10}$ The divisions between different Forms or types are not exact but may be regarded as points in a continuum, as observed by Hilary Cool and Jennifer Price. ${ }^{11}$

Among the finds are nine unguent flasks of Isings Form 28, which date to the first century CE (Fig. 1). ${ }^{12}$ These include a single unguent bottle of Isings Form 8 (first century CE) ${ }^{13}$ and one amphoriskos-shaped unguent bottle of Isings Form 9. ${ }^{14}$ This category of vessels consists of no less than 44 'candlestick unguent bottles' (unguentaria of Isings Form 82) (Fig. 2), making up some 30 per cent of the total collection. ${ }^{15}$ These were first introduced in the eastern Mediterranean in the last quarter of the first century and continued to be in use until the mid-third century CE. ${ }^{16}$ A small flagon just $134 \mathrm{~mm}$ high - may also belong to this group. ${ }^{17}$

There is a single fusiform unguent flask of Isings Form 105 (dating to the fourth century CE) (Fig. 3), ${ }^{18}$ alongside an additional flask of a related type, but with a funnel mouth (the shape and colour of this vessel also points to a fourth-century CE date). ${ }^{19}$ There are eight late Roman (late third- to fifth century CE) unguent flasks with wide necks and piriform to globular bodies (Fig. 4$)^{20}$ and six jars or flasks which resemble the unguent flasks of Isings Form 28, but are smaller. ${ }^{21}$ In addition to these there are

\footnotetext{
9 Barag 1976, 198.

10 Isings 1957.

11 Cool \& Price 1995, 161. Despite the drawbacks in Clasina Isings' typology (1957), it still maintains the advantage of being widely understood and accepted; and rather than attempting to reclassify material studied by other scholars, the majority of which employ Isings, I have chosen to refer to her work.

${ }^{12}$ C40735, C40736, C40738-40740, C40744, C41240, C42473. Weinberg \& Stern 2009, 57 and 79.

13 C40741. Isings 1957, 24.

${ }^{14}$ C41232. Isings 1957, 24-25.

15 C40706-40732, C40734, C40742-40743, C41237-41239, C41241-41243, C42154, C42165-

42168, C42472, C42474.

16 Weinberg \& Stern 2009, 105.

${ }^{17}$ C40750. A similar find comes from Hantita, Israel (Barag 1978, 27, fig. 13, 56.).

${ }_{18}$ C40767. Isings 1957, 126; Barag 1976, 202.

${ }^{19} \mathrm{C} 40765$.

${ }^{20}$ C40696-40701, 40703-40704. Bagatti \& Milik 1958, 144, fig. 34, 1-5.

${ }^{21}$ C40694, C40695, C40702, C42150, C42170, C42171.
} 


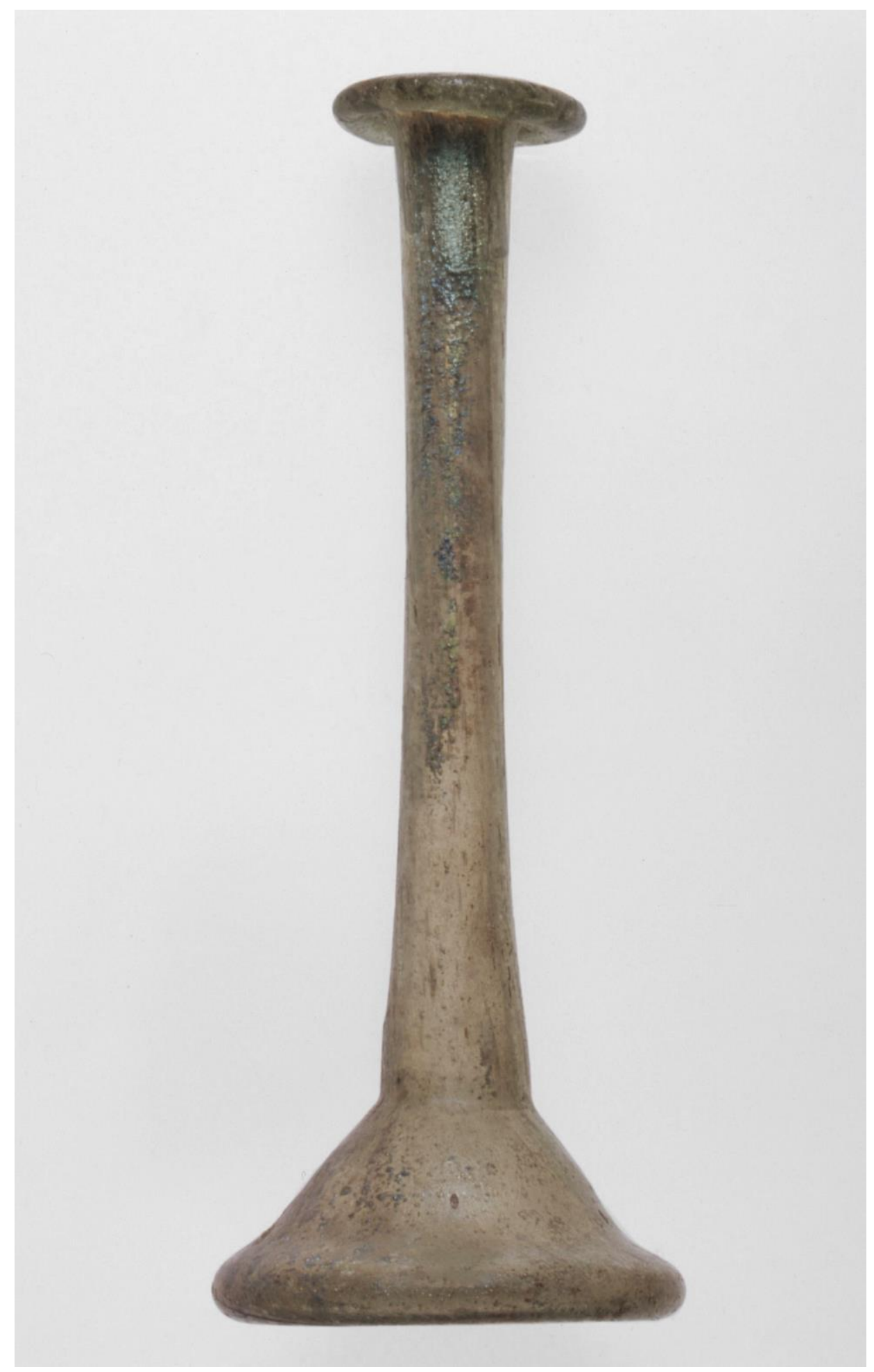

Fig 1 Unguentarium. Transparent, medium thick glass. Some lime encrustations inside. H. $12.0 \mathrm{~cm}$. Second/third century CE. Oslo, MCH, inv. C40739.

Photograph: (C) Lill-Ann Chepstow-Lusty for MCH, UiO. 


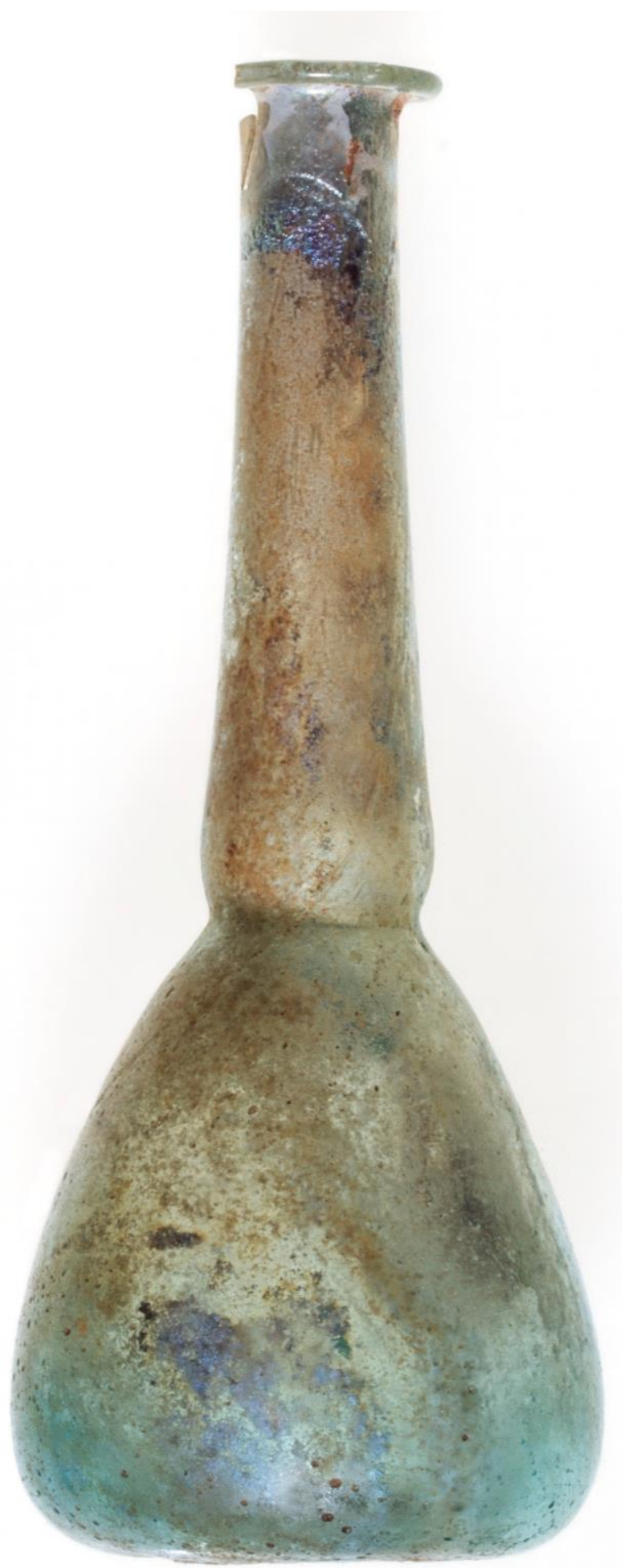

Fig. 2 Unguentarium. Transparent, thin glass. Many bubbles, some large, with lime enscrustations inside. H. $16.4 \mathrm{~cm}$. Second/third century CE. Oslo, MCH, inv. C40725. Photograph: (C) Lill-Ann Chepstow-Lusty for MCH, UiO. 


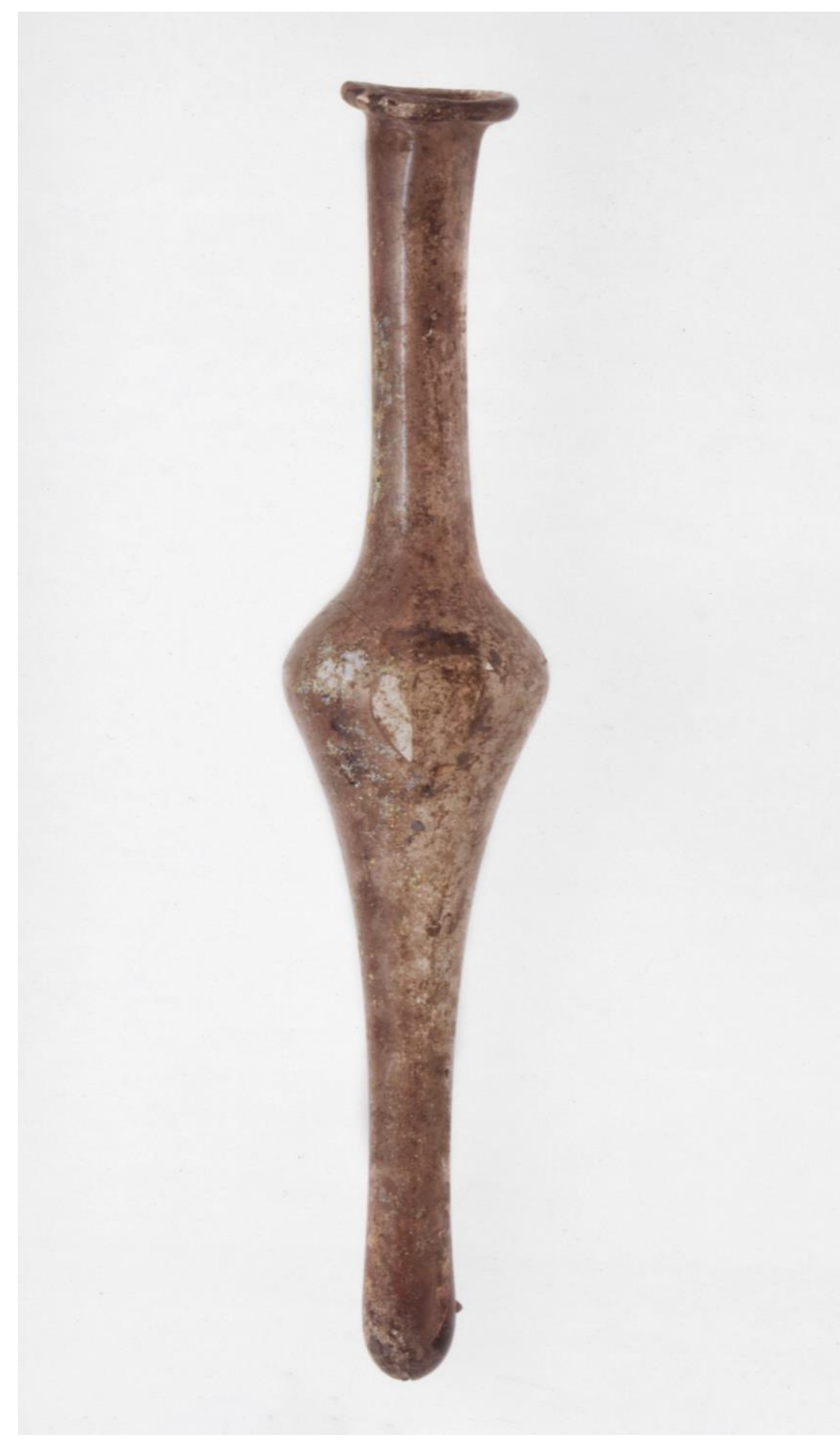

Fig. 3 Unguentarium. Transparent, thin glass with bubbles and some lime encrustations inside. Weak rainbow-coloured iridescence. H. $16.5 \mathrm{~cm}$. Fourth century CE. Oslo, MCH, inv. C40767. Photograph: (C) Lill-Ann Chepstow-Lusty for MCH, UiO. 


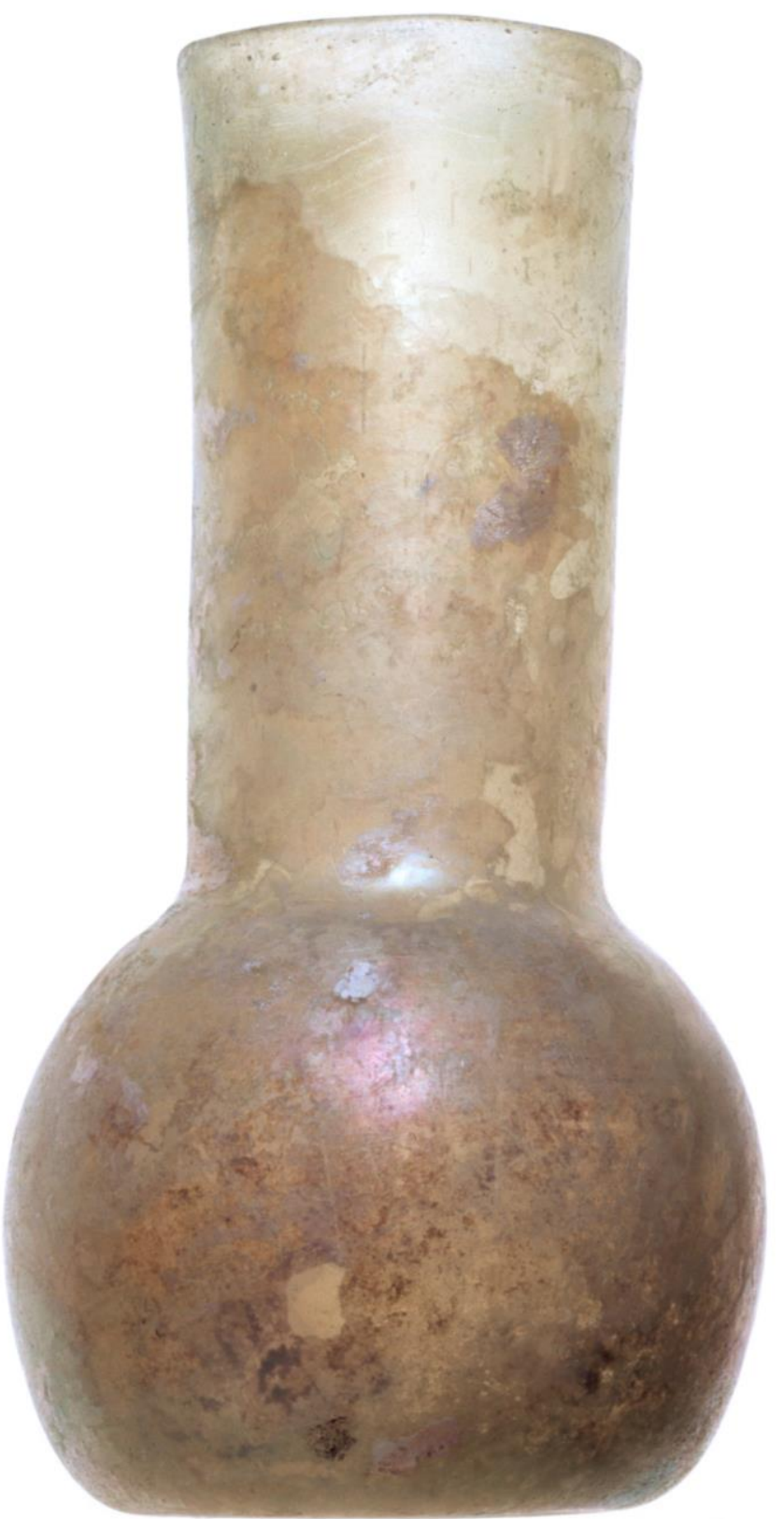

Fig. 4 Unguentarium. Transparent, medium thin glass with thin, flaking creamcoloured crust inside and weak rainbow-coloured iridescence. H. $12.0 \mathrm{~cm}$. Fourth/fifth century CE. Oslo, MCH, inv. C40698. Photograph: (C) Lill-Ann Chepstow-Lusty for MCH, UiO. 


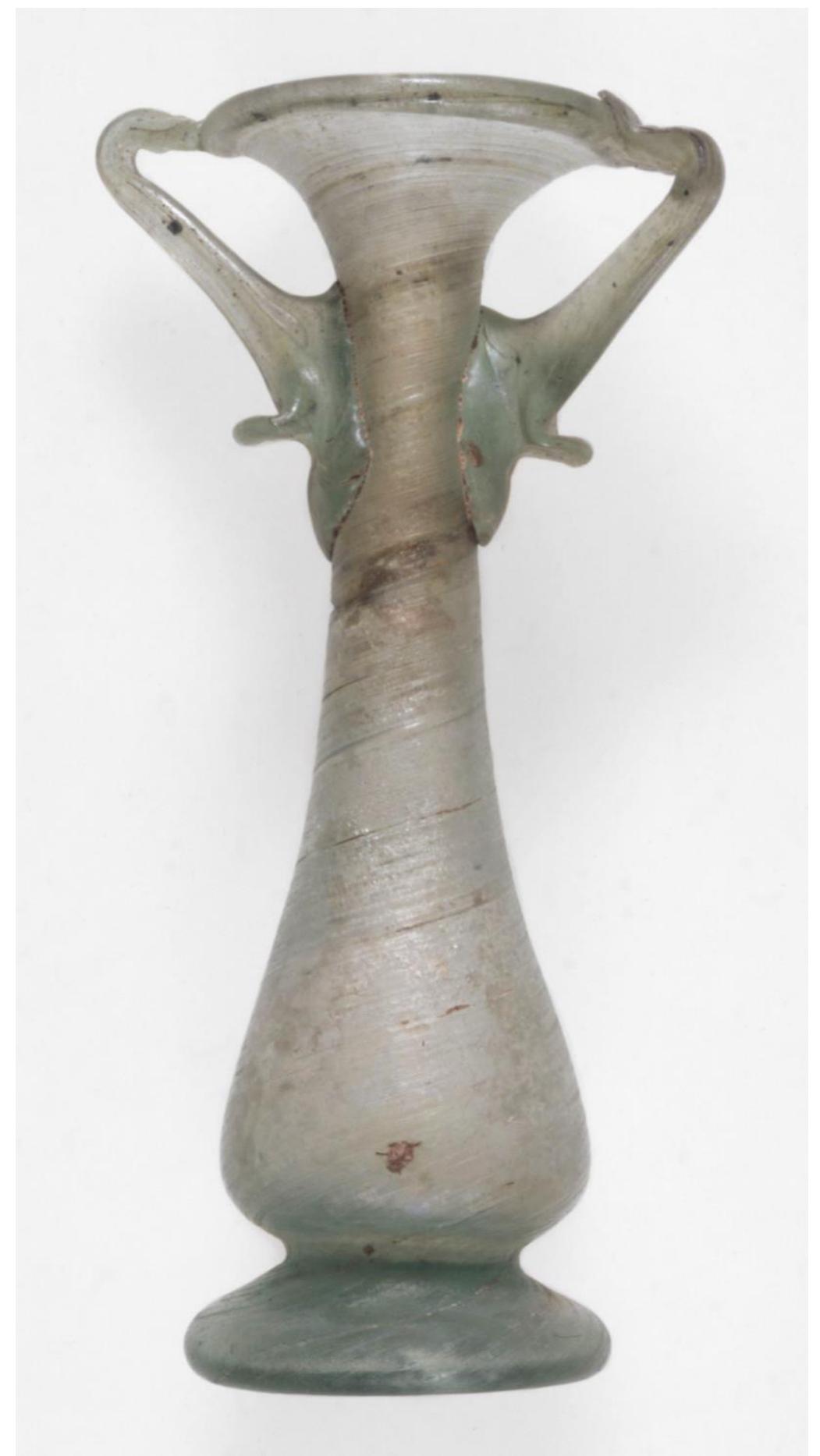

Fig. 5 Balsamarium. Second century CE. Oslo, MCH, inv. C41234. H. $12.0 \mathrm{~cm}$. Photograph: (C) Lill-Ann Chepstow-Lusty for MCH, UiO. 


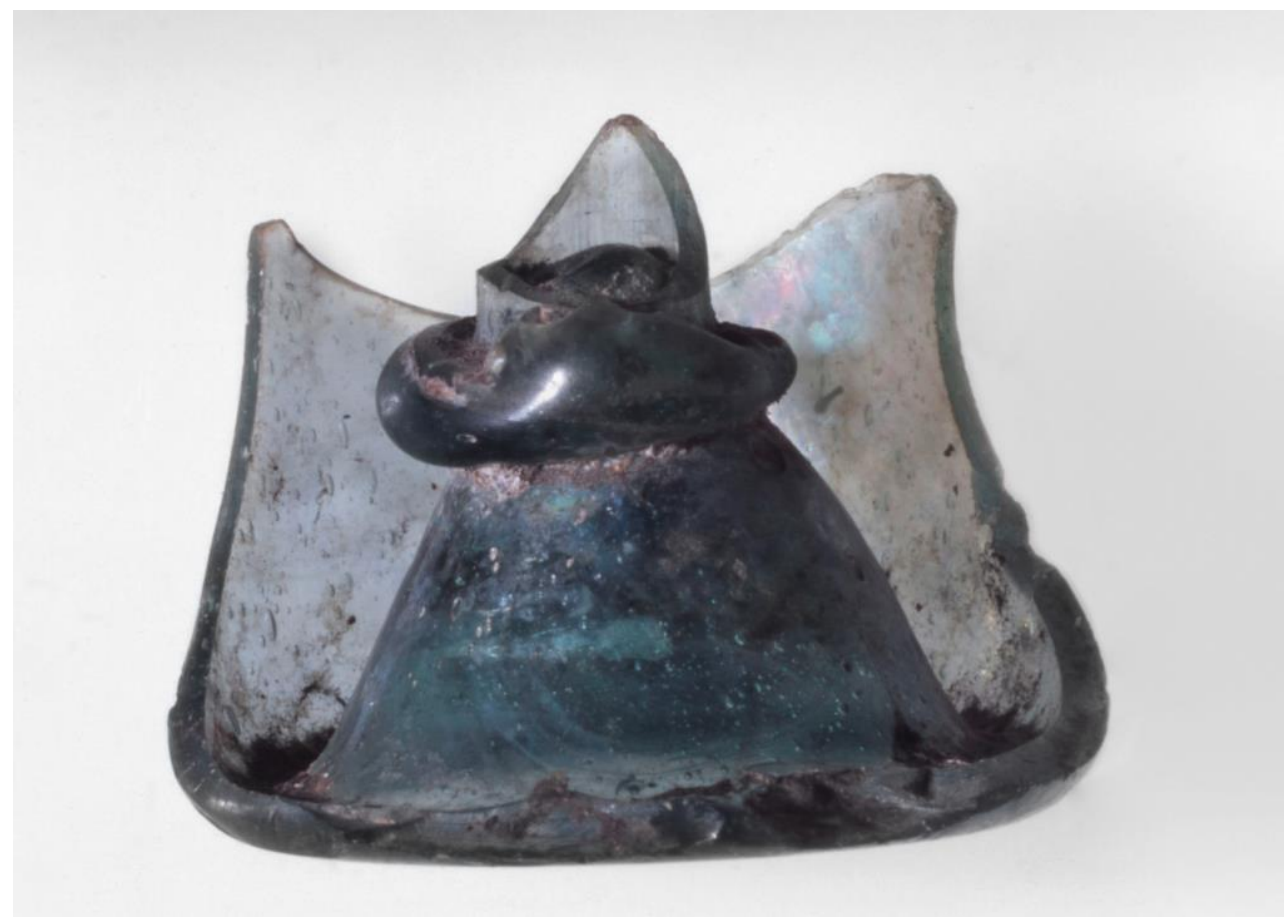

Fig. 6 Glass fragment. Transparent, medium thick glass with many bubbles. H. $2.2 \mathrm{~cm}$. Oslo, $\mathrm{MCH}$, inv. C40780. Photograph: (C) Lill-Ann Chepstow-Lusty for MCH, UiO.

thirteen late Roman (third- to fourth century CE) unguent flasks of various shapes. A number of flasks and bottles, including a cylindrical jug of Isings Form $126,{ }^{22}$ a tall cylindrical bottle with two handles of Isings Form 127 of late third- to fourth-century CE date, ${ }^{23}$ nine flasks of Isings Form $104 b^{24}$ and one flask of Isings Form 103 or 104b also make up the Ustinow collection. ${ }^{25}$ Three fragmentary lamps of Late Roman or Early Byzantine date with internal wick-holds are also part of the collection (Fig. 6. C40782) ${ }^{26}$ These are of a type that is commonly found in the East, but rarely in the West. ${ }^{27}$ In addition to these, fragments from the lower body and base of a conical lamp of Uboldi type III, a type manufactured in the fifth- to seventh centuries CE (Fig. 7. C40779), were also among the items. ${ }^{28}$ The latter type, in contrast, is also common in the West. ${ }^{29}$

${ }^{22}$ C41231. Isings 1957, 156-157.

${ }^{23}$ C40690. Isings 1957, 157-158.

${ }^{24}$ C40486, C40677, C40678, C40679, C40681, C40683, C42204, C42205, C42470. Isings 1957, 123-124.

${ }^{25}$ C40680. Isings 1957, 121-124.

${ }^{26}$ C40733, C40780, C40782. Weinberg \& Stern 2009, 153-154, ill. 12, fig. 21, pl. 33.

${ }^{27}$ Stern 1999, 480.

${ }^{28}$ This fragment resembles a lid of Isings Form 66; however, the colour and shape testify to the fact that it was a lamp rather than a lid. C40779. Uboldi 1995, 110-116.

${ }^{29}$ See for example: Saguì 2000, 206; Sternini 2001, 28. 


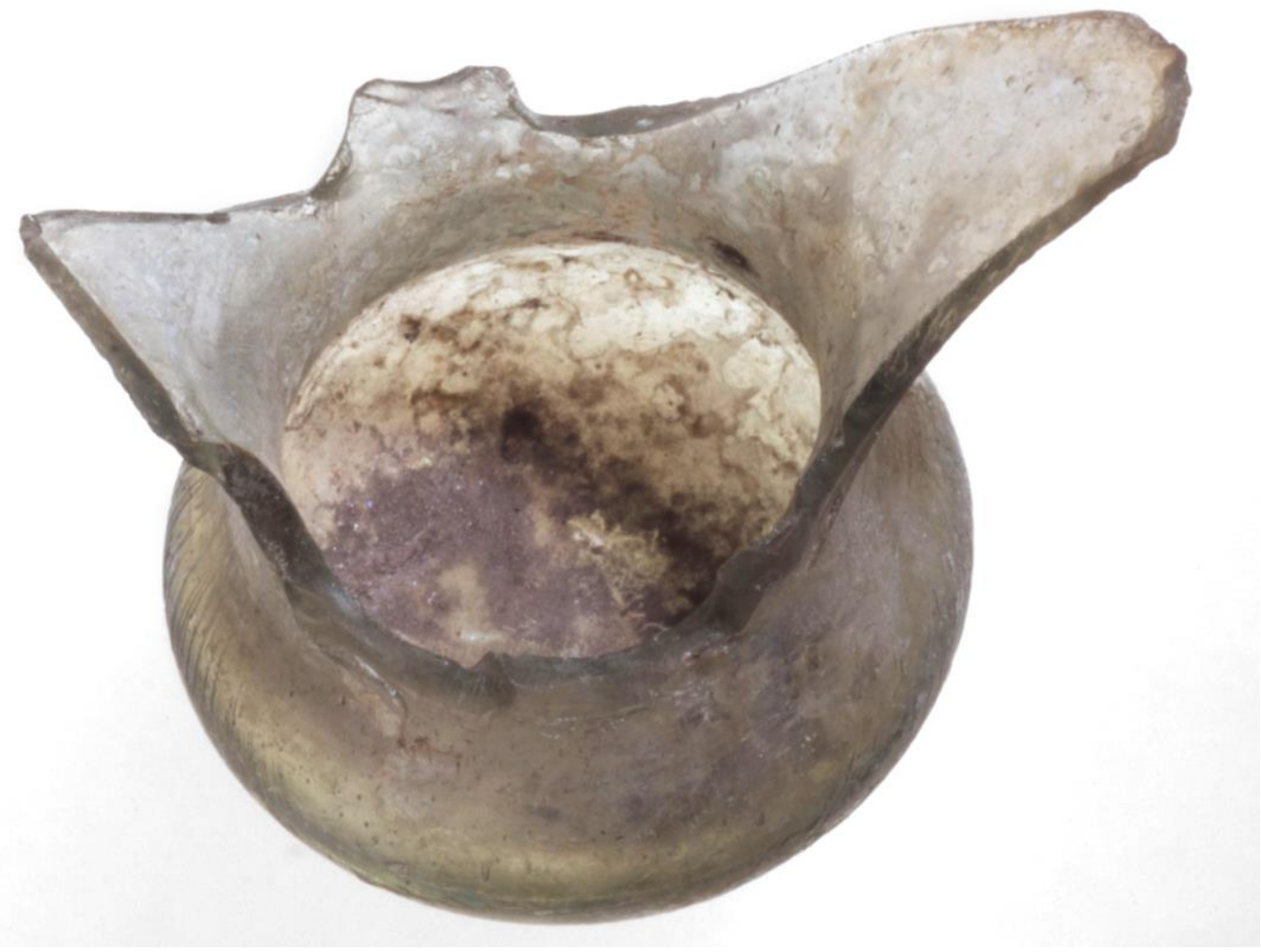

Fig. 7 Glass fragment. Conical body with globular top; pontil-mark on top. H. $3.7 \mathrm{~cm}$. Oslo, MCH, inv. C40779. Photograph: C Lill-Ann Chepstow-Lusty for MCH, UiO.

The origin and original context of the glass vessels in the von Ustinow collection Unlike other contemporary collectors, von Ustinow does not appear to have acquired the antiques from art-dealers. Rather, they seem to be the result of cooperating with professional excavators, chiefly the orientalist and archaeologist Charles ClermontGanneau (1846-1923). ${ }^{30}$ Some finds, however, were purchased from impoverished farmers and craftsmen living in the area, and a letter to the British-Norwegian businessman K. F. Knudsen, written in 1913 reveals that von Ustinow regarded this as an act of 'moral duty'. 31

As already mentioned, much points to the glass in the von Ustinow collection having originated from funerary contexts in the Syro-Palestinian area. The main argument for this is the striking resemblance with the glass assemblages that archaeological excavations have unearthed in a number of rock-cut tombs in central

30 Berczelly 1999, esp. 7, 12.

31 Berczelly 1997, 32. 
and southern Israel, ${ }^{32}$ rock-cut tombs in Israel, for instance at Beth She'arim, Galilee ${ }^{33}$ and the Mount of Olives, Jerusalem. ${ }^{34}$ In contrast, this collection is markedly different from the glass from other funerary contexts in northern Israel, for instance the material from Hanita, in western Galilee. Excavations of burial tombs in the latter area have yielded very few unguentaria, but instead a multitude of bowls, and to some extent also bottles and beakers. ${ }^{35}$

A number of the vessel types represented in the collection are primarily distributed in the Syro-Palestinian area, such as the type known as 'kohl bottles'. ${ }^{36}$ Other vessel types were in use throughout the Roman Empire, such as the 'candlestick unguent flasks', ${ }^{37}$ but are particularly prolific finds in the Syro-Palestinian area. ${ }^{38}$ Frellumstad's contention that a substantial part of the collection comes from Jaffa rests on two arguments. Firstly, as previously noted, it is known that von Ustinow acquired many objects from local residents living in the Jaffa-area. Secondly, a small number of published objects from late nineteenth-century excavations from rock-cut tombs in Ard Tabitha ${ }^{39}$ (in the vicinity of the city Jaffa) closely resemble the actual finds in the von Ustinow Collection. ${ }^{40}$ These were published in the Palestine Exploration Quarterly by Baurath von Schick, ${ }^{41}$ who also notes that his visit to the site was accompanied by 'Baron Ustinoff'. ${ }^{42}$

Frellumstad argues that parts of the collection stem from the area around Jaffa. von Ustinow settled in Palestine in 1862. He built a house near the sea in Jaffa and bought a town house in Jerusalem. With the exception of the years 1867 to 1878, he remained in Palestine until 1913. ${ }^{43}$ Given the fact that he lived in both Jaffa and Jerusalem - and that the collection resembles material from funerary contexts found in both Jaffa ${ }^{44}$ and Jerusalem ${ }^{45}$ - objects could well have originated from either or both of these places. Or, indeed, from some other part of the Syro-Palestinian area which has yielded similar glass assemblages.

\footnotetext{
32 Harden 1949; Barag 1981.

33 Barag 1976.

34 Bagatti \& Milik 1958, 141-153.

35 Barag 1978; 1981, 80.

36 Hayes 1975, 82-83; Barag 1976, 201; Whitehouse 2001, 190-191.

37 Isings Form 82 (957, 97-99); see also Whitehouse 1997, 147-160.

38 Harden 1949, 155; Barag 1962, 212; 1963, 104; 1978, 54; Hayes 1975, 42.

39 This area was partly owned by the Russian Archmandrite, who had several of the rock-tombs in this area 'cleared out' (von Schick 1893, 287). Inscriptions strongly indicate that these tombs were Jewish (see von Schick 1893, fig. 7).

${ }^{40}$ von Schick 1883, figs. 11 no. 3 and 4; Frellumstad 2007, 50 and 55.

${ }^{41}$ Baurath von Schick was a resident in Jerusalem since the 1850 s and was keenly interested in the archaeology and history of the area, and seems to have been a good friend of Plato von Ustinow (Anonymous 1893, 272; von Schick 1893, 294).

42 von Schick 1893, 286.

43 Berczelly 1997, 31.

${ }^{44}$ Frellumstad 2007, 58.

45 Bagatti \& Milik 1958, 141-153.
} 


\section{The function of the vessels and objects}

As mentioned above, the intact state of the vessels demonstrates that they originate from funerary contexts, most likely from rock-cut tombs in southern and central Israel. These rock-cut tombs were used as family vaults for centuries, and the deceased were buried alongside their ancestors. ${ }^{46}$ The vessels and objects in the von Ustinow Collection represent an extended period of time; omitting objects that probably come from other contexts, at least six centuries are represented. So, although a number of finds may well come from the same tombs, they represent multiple burials which could have taken place over the centuries.

How, then, are we to interpret the function of these vessels and objects? Are they to be seen as grave gifts? Were they linked to funerary rituals? Or do they represent objects used in the burial rituals and associated ceremonies, objects which were then given to the deceased? The latter interpretation seems the most probable to me, and I argue below that these finds are predominantly linked to the rituals and ceremonies related to both primary and secondary burial.

In my view, this could explain most types of vessels and objects in the von Ustinow Collection: the strong emphasis on vessels linked to perfume and cosmetics, such as perfume bottles, small jars and kohl-flasks, is probably linked to the preparation of the deceased before burial. The perfume bottles could also be related to the treatment of the bones during secondary burial rites. The flasks, flagons and beakers may have been used for funerary meals, ${ }^{47}$ or it is possible that they functioned as grave gifts. Finally, the lamps are likely to have been used when entering the dark tombs. Vessels of different date may have had the same function - preparing the deceased as part of the funeral rituals - but it has to be borne in mind that they were in no other way linked to each other.

Scented oils and fragrant spices are mentioned as being used in funerary rituals in Jewish, Christian and Pagan sources. ${ }^{48}$ For instance, a passage in The Tosefta (Sheqalim 1.12) mentions the use of perfume in funerary rituals: 'or they sprinkle perfume before his bier'. ${ }^{49}$ The New Testament (Matthew 26:6-12) ${ }^{50}$ also mentions the use of a perfume, or balm, in primary burial rituals:

While Jesus was in Bethany in the home of a man known as Simon the Leper, a woman came to him with an alabaster jar of very expensive perfume, which she poured on his head as he was reclining at the table. When the disciples saw this, they were indignant. 'Why this waste?' they asked. 'This perfume

\footnotetext{
46 Barag 1981, 76.

47 Frellumstad 2007, 66.

48 Jewish and Christian contexts: Tosefta Sheqalim 1:12; Babylonian Berakhot, 53a; Tanhuma, ed. Buber, 58:6; Matthew 26:6-12; John 19:39-40; Mark 16.1. Barag 1972, 26; Dayagi-Mendels 1993, 90. Pagan contexts, see for example: Lucian, De Luctu, 11; Classen, Howes \& Synnott 1994, 4244; Lindsay 2000, 162.

49 Translation Jacob Neusner 1981; The translation by Frowald G. Hüttenmeister and Göran Larsson (1997) notes that the bier was sprinkled with wine containing balm.

${ }^{50}$ Bible citations from New International Version (NIV), pub. Hodder \& Stoughton, London 1978.
} 
could have been sold at a high price and the money given to the poor.' Aware of this, Jesus said to them, 'Why are you bothering this woman? She has done a beautiful thing to me. The poor you will always have with you, but you will not always have me. When she poured this perfume on my body, she did it to prepare me for burial'.

Chemical analysis has been undertaken for the residues in a small number of 'candlestick unguent bottles' (Isings Form 82), including two from funerary contexts in Jerusalem; the results of these demonstrated that they had once contained olive oil. $^{51}$ Such observations might attest to their function as perfume containers. 'Theophrastus' (c. 370 - c. 285 BCE) work De Odoribus gives a detailed description on how to manufacture perfumes. These were based on different types of oil ${ }^{52}-$ almond oil, balanos oil, sesame oil and olive oil ${ }^{53}$ - although Theophrastus thought that olive oil was the least appropriate for preparing perfumes. ${ }^{54}$

The long neck typical of the 'candlestick unguent bottles' had the function of stopping the perfume from evaporating, at least this is what a passage in the Mishnah describes. ${ }^{55}$ Studies of the remains in bottles of this type from the Bay of Naples area, Italy, demonstrates that they once contained an oil-based perfume or skin emollient: beeswax, Pinacea resin and waxes from flowers or leaves. ${ }^{56}$

Preparing fragrant spices and perfumes for funerary purposes is, for example, made clear in a passage in the Mishnah (Babylonian Berakhot 53a), which states 'the reason we do not recite a blessing over fragrant spices of the dead is because it is placed there to remove the odor of the decaying corpse, rather than for the smelling of its fragrance'. ${ }^{57}$ Therefore, much points to the fact that finds of this type were also linked to the secondary funerary rituals performed, for another passage in the Mishnah shows that wine scented with perfumes was sprinkled on the bones of the deceased, ${ }^{58}$ and stains on bones found in rock-cut tombs seem to confirm this tradition. ${ }^{59}$

The von Ustinow Collection includes a number of kohl-tubes with single or multiple compartments. This vessel type is generally viewed, as the name suggests, as a container for kobl (black eye-liner). Occasionally, finds have been left unwashed and still contain residues of their original contents, and analysis of the remains in a number

${ }^{51}$ Barag 1972, 24-25; Basch 1972; Greenewalt et al.,1985, 84-85.

${ }^{52}$ The use of alcohol as the basis of perfume is often viewed as a relatively recent invention, distilled alcohol being a late invention (Brun 2000, 277). But, it is clear that wine was employed at least from Hellenistic times. Theophrastus argues that the admixture of wine in certain perfumes, for instance those containing myrrh, was to make them more fragrant (Theophrastus, De Odoribus, 14.67).

${ }^{53}$ Theophrastus, De Odoribus, 4.14-16. See also Mattingly 1990, 80-81.

${ }^{54}$ Theophrastus, De Odoribus, 4.14.

${ }_{55}^{5}$ Dayagi-Mendels 1993, 105 referring to Mishnah, Parah, 12.2

56 Ribechini et al. 2008.

57 Translation by Schorr \& Malinowitz (1997).

${ }^{58}$ Mishnah, Semahot 12.9 (Cohen 1971).

${ }^{59}$ Dayagi-Mendels 1993, 130-132. 
of kohl-tubes from the Near East (now part of collections in several American Museums) demonstrate that they had once contained galena (lead sulphide). ${ }^{60}$ Galena was used in Ancient Egypt as an eye-liner, a tradition that continued in the Near East until the Roman and Byzantine periods. ${ }^{61} \mathrm{~A}$ passage in the Talmud (Babylonian Berakhot 18b) mentions a woman who wanted to be buried with her comb and kohltube. Finds from funerary contexts support the view that they were used for makeup, as they have been found together with mirrors. ${ }^{62}$ But are these finds only to be viewed as grave gifts? A hypothesis is that they put make-up on the deceased as part of the preparation before burial.

The collection holds two small vessels of a type called 'beaker-shaped' vessels by Dan Barag. ${ }^{63}$ Not only are they of too small a size to be considered as actual beakers (the rims being a mere $49-50 \mathrm{~mm}$ in diameter), but parallels display other functions of these vessels, namely as containers for cosmetics. Several scholars have pointed to the difficulties in establishing the function of vessels of this and related types, and how different designations such as 'beaker' can be misleading. Olof Vessberg has argued that some so-called beakers actually 'served as salve pots', and that some may have had lids. ${ }^{64}$ Finds of a similar type to those in the von Ustinow Collection come from Hanita, Israel and these may also have had lids. ${ }^{65}$ Egyptian evidence supports the view that they were used for salves or kohl, and a find of this type from Karanis had two bone pins stuck into the vessel through a cloth cover. ${ }^{66}$

The functions of the cylindrical jug of Isings Form 126, the tall cylindrical bottle with two handles of Isings Form 127, the flasks of Isings Forms 104 and the flask of Isings Form 103, cannot be established with certainty. However, other examples show that these could have been employed for storing or serving wine. Clasina Isings has argued that Form 104 (a flask with a funnel mouth) could be an imitation of blackvarnished pottery flasks with good-health wishes. ${ }^{67}$ In my view, this strengthens the argument that they were linked with wine, and these finds may be related to funerary meals held in the tombs.

Four fragmentary lamps of Late Roman or Early Byzantine date also form part of the collection. Glass lamps ${ }^{68}$ were used in different contexts - religious edifices

\footnotetext{
${ }^{60}$ Blanchard, Stern \& Stodulski 1992.

${ }^{61}$ Dayagi-Mendels 1993, 36-42. Soot (fuligo lat.) - was a substitute for kohl (i.e. galena), see also Olson 2009, 298-299), and chemical analysis of remains from a number of cosmetic containers in glass from Pompeii have demonstrated this (Gamberini et al. 2008).

${ }^{62}$ Whitehouse 2001, 192-193.

63 Barag 1978, 30.

64 Vessberg 1952, 118-119.

65 Barag 1978, 30-31.

${ }^{66}$ Harden 1936, 132.

${ }^{67}$ Isings 1957, 123.

${ }^{68}$ Marianne Stern has argued that the glass lamp is an eastern Mediterranean, possibly Syro-

Palestinian, invention. It burns longer and about twice as bright as a terracotta lamp (Stern 1999,
} 
such as synagogues and churches, also bath-houses and private houses ${ }^{69}$ - and also in graves. ${ }^{70}$ It is highly likely that these originate from the same context as the remainder of the material, rock-cut tombs, and they must have been a practical necessity in the pitch-black environment.

\section{Summary}

As demonstrated throughout this study, we know more about the context and function of the glass in the von Ustinow Collection than many other museum collections. All evidence suggests that this material derives from a number of rock-cut tombs in southern and central Israel, and that these finds may be linked to the rituals and ceremonies involved with primary and secondary burial. Scented oils, perfumes and cosmetics were used in preparing the deceased for burial, and a majority of the vessels in the collection are containers used for this purpose. The finds also include a small number of vessels employed for serving wine, and in all likelihood, these were left behind after funerary meals. Finally, there are a small number of lamps - lamps used for bringing light to the dark tombs.

Docent Dominic Ingemark

Dept of Archaeology and Ancient History

Uppsala University, Sweden

E-mail address: dominic.ingemark@antiken.uu.se

479). See also the useful survey of Gorin-Rosen \& Katsnelson 2007, 73-154 on local glass production from Khirbat el-Ni'ana.

${ }^{69}$ Prudentius $(348$ - c. $410 \mathrm{CE})$ describes the hanging glass lamps in the church (Liber Cathemerinon, 5.153-156). A fifth-century ostracon from Egypt, a record of inventories, or more specifically a list of lamps, for a church starts with glass lamps (Montserrat 1995, 439-440).

Archaeological finds are known from a number of different contexts, see Crowfoot \& Harden 1931, 196; Stevenson 1988, 207; Stern 1999, 480; O’Hea 2007. See also Olcay 2001 for finds of later Byzantine date.

${ }^{70}$ Bagatti \& Milik 1958, 146-148; Barag 1976, 200-206; Hadad 1998. 


\section{References}

Anonymous 1893: 'Annual Meeting', PEFQ (October 1893): 269-281.

Bagatti, P. B. \& Milik, J. T. 1958: Gli scavi del "Dominus Flevit" Monte Oliveto Gerusalemme), Parte 1: La necropoli del periodo romano. Franciscan Printing Press: Jerusalem.

Barag, D. 1962: 'Glass Vessels from the Cave of Horror', Isr. Explor. J. 12(3-4): 209214.

Barag, D. 1963: 'The Glassware', in Y. Yadin (ed.), The Finds from the Bar Kokhba Period in the Cave of Letters, 101-110. Jerusalem: The Israel Exploration Society.

Barag, D. 1972: 'Two Roman Glass Bottles with Remnants of Oil', Isr. Explor. J. 22(1): 24-26.

Barag, D. 1976: 'Glass Vessels', in N. Avigad (ed.) Beth She'arim Report on the Excavations During 1953-1958, Vol. 3: Catacombs 12-23, 198-209. Jerusalem: Massada Press

Barag, D. 1978: Hanita, Tomb XV - A Tomb of the Third and Early Fourth Century CE. Jerusalem: Department of Antiquities and Museums, Ministry of Education and Culture.

Barag, D. 1981 : 'Towards a Chronology of Syro-Palestinian Glass', in Annales du $8 e$ Congrès Internationale d'Etude Historique du Verre: Londres-Liverpool, 18-25 septembre 1979, 73-81. Liege: Association Internationale pour l'Histoire du Verre.

Basch, A. 1972: 'Analyses of Oil from Two Roman Glass Bottles', Isr. Explor. J. 22(1): 27-32.

Berczelly, L. 1997: 'Norges største antikksamling fra Middelhavslandene: Ustinowsamlingens historie', Nicolay 72: 30-39.

Berczelly, L. 1999: 'Norges største antikksamling fra Middelhavslandene 2: hva kan Ustinow-samlingen fortelle?', Nicolay 78: 4-15.

Blanchard, W. D, Stern, E. M \& Stodulski, L. P. 1992: 'Analysis of Materials Contained in Mid-4th to Early 7th-century A.D. Palestinian Kohl Tubes', in P. B Vandiver (ed.), Materials issues in art and archaeology III: symposium held 27 April-1 May 1992, San Francisco, Vandiver, 239-253. Pittsburgh: Materials Research Society

Brun, J.-P. 2000: 'The Production of Perfumes in Antiquity: The Cases of Delos and Paestum', AJA 104(2): 277-308. 
Clairmont, C. W. 1977: Catalogue of Ancient and Islamic Glass (Based on the Notes of C. J. Lamm). Athens: Benaki Museum.

Classen, C., Howes, D. \& Synnott, A. 1994: Aroma. The Cultural History of Smell. London \& New York: Routledge.

Cohen, A. (ed.) 1971: The minor tractates of the Talmud: Massektoth Ketannoth. London: The Soncino Press.

Cool, H. E. M \& Price, J. 1995: Roman Vessel Glass from Excavations in Colchester, 1971 85. Colchester: Colchester Archaeological Trust.

Crowfoot, G. M \& Harden, D. B. 1931: 'Early Byzantine and Later Glass Lamps', JEA 17 (3-4): 196-206.

Cummings, K. 1980: The Technique of Glass Forming. London: Batsford.

Dayagi-Mendels, M. 1993: Perfumes and Cosmetics in the Ancient World. Jerusalem: The Israel Museum.

Frellumstad, R. 2007: 'Glass in the Ustinow Collection - Objects without Context', unpublished MA-thesis, $\mathrm{UiO}$.

Gamberini, M. C., Baraldi, C., Palazzoli, F., Ribechini, E. \& Baraldi, P. 2008: 'MicroRaman and Infrared Spectroscopic Characterization of Ancient Cosmetics', Vib. Spectrosc. 47(2): 82-90.

Gorin-Rosen, Y. \& Katsnelson, N. 2007: 'Local Glass Production in the Late RomanEarly Byzantine Periods in Light of the Glass Finds from Khirbat el-Ni'ana', Atiqot 57: 73-154.

Greenewalt, C. H. Jr, Sullivan, D. G, Ratté, C. \& Howe, N. T. 1985: 'The Sardis Campaigns of 1981 and 1982', BASOR 23: 53-92.

Hadad, S. 1998: 'Glass Lamps from the Byzantine through Mamluk Periods at Bet Shean, Israel', JGS 40: 63-76.

Harden, D. B. 1936: Roman Glass from Karanis: Found by the University of Michigan Archaeological Expedition in Egypt, 1924-29. Ann Arbor: University of Michigan Press.

Harden, D. B. 1949: 'Tomb-Groups of Glass of Roman Date from Syria and Palestine', Iraq 11: 151-159. 
Hayes, J. W. 1975: Roman and Pre-Roman Glass in the Royal Ontario Museum. Toronto: Royal Ontario Museum.

Ingemark, D. 2014: Glass, Alcohol and Power in Roman Iron Age Scotland. Edinburgh: National Museums Scotland.

Isings, C. 1957: Roman Glass from Dated Finds. Groningen: J. B. Wolters.

Israeli, Y. 1991: 'The invention of blowing', in M. Newby \& K. Painter (eds), Roman Glass: Two Centuries of Art and Innovation, 46-55. London: Society of Antiquaries of London.

Israeli, Y. 1998: The Wonders of Ancient Glass at the Israel Museum, Jerusalem. Jerusalem: The Israel Museum.

Israeli, Y. 2005: 'What Did Jerusalem's First Cent. BCE Glass Workshop Produce?', in A-.D. Nenna (ed.), Annales du 16e Congrès de l'Association Internationale pour l'Histoire du Verre, London, 7-13 September, 2003, 54-57. Nottingham: Association Internationale pour l'Histoire du Verre.

Israeli, Y. \& Katsnelson, N. 2006: 'Refuse of a Glass Workshop of the Second Temple Period from Area J', H. Geva (ed.), Jewish Quarter Excavations in the Old City of Jerusalem, Conducted by Nahman Avigad, 1969-1982, Vol. III: Area E and Other Studies, Final Report, 411-460. Jerusalem: Israel Exploration Society.

Lierke, R. 1993: 'Aliud Torno Teritur' - Rippenschalen und die Spuren einer Unbekannten Glastechnologie: Heißes Glas aus der Töpferscheibe', Antike Welt 24: $218-234$

Lierke, R. 1996 : 'Glass Vessels Made on a Turning Wheel in Roman Times (Survey)', in A. Van Wiechen \& P. C. Ritsema Van Eck (eds), Annales du 13 e Congrès de l'Association Internationale pour l'Histoire du Verre: Pays Bas 1995, 55-62. Lochem: Association Internationale pour l'Histoire du Verre.

Lierke, R. 1999: Antike Glastöpferei: Ein vergessenes Kapitel der Glasgeschichte. Mainz: Verlag Philipp von Zabern.

Lindsay, H. 2000: 'Death-Pollution and Funerals in the City of Rome', in V. M. Hope \& E. Marshall (eds), Death and Disease in the Ancient City, 152-173. London \& New York: Routledge. 
Mattingly, D. J. 1990: 'Paintings, Presses and Perfume Production at Pompeii', OJA 9(1): 71-90.

Miles, G. C. 1963: Contributions to Arabic Metrology II. Early Arabic Glass Weights and Measure Stamps in the Benaki Museum, Athens, and in the Peter Ruthven Collection, Ann Arbor. New York: American Numismatic Society.

Montserrat, D. 1995: 'Early Byzantine church lighting: a new text', Orientalia 64(4): 430-444.

O'Hea, M. 2007: 'Glass in Late Antiquity in the Near East', in L. Lavan, E. Zanini \& A. Sarantis (eds), Technology in Transition A.D. 300-650, 233-248. Leiden, Brill.

Olcay, B. Y. 2001: 'Lightning Methods in the Byzantine Period and Findings of Glass Lamps in Anatolia', JGS 43: 77-87.

Olson, K. 2009: 'Cosmetics in Roman Antiquity: Substance, Remedy, Poison', CW 10(3): 291-310.

Ribechini, E., Modugno. F., Colombini, M. P. \& Evershed, R. P. 2008: 'Gas Chromographic and Mass Spectrometric Investigations of Organic Residues from Roman Glass Unguentaria', J. Chromatogr. 1183 (1-2): 158-169.

Saguì, L. 2000: 'Produzioni vetrarie a Roma tra V e VII secolo. Nuovi dati archeologici', D. Whitehouse (ed.), Annales du 14e Congrès de l'Association Internationale pour l'Histoire du Verre, Venezia-Milano 1998, 203-207. Lochem: Association Internationale pour l'Histoire du Verre.

Stern, E. M. 1999: 'Roman Glassblowing in a Cultural Context', AJA 103 (3): 441484.

Stern, E. M. 2004: 'The Glass Banausoi of Sidon and Rome’, in M. Beretta (ed.), When Glass Matters: Studies in the History of Science and Art from Graeco-Roman Antiquity to the Early Modern Era, 77-120. Florence: Olschki.

Stern, E. M. 2008: 'Glass Production', in J. P. Oleson (ed.), The Oxford Handbook of Engineering and Technology in the Ancient World, 520-548. Oxford: Oxford University Press.

Stern, E. J. \& Gorin-Rosen, Y. 1997: ‘Burial Caves Near Kabri’, Atiqot 33:1-22.

Sternini, M. 2001: 'Reperti in vetro da un deposito tardoantico sul Colle Palatino', JGS 43: 21-75. 
Stevenson, J. 1988: 'Glass Lamps from San Vincenzo al Volturno, Molise', PBSR 56: 198-209.

Tal, O. \& Taxel, I. 2015 (eds): Samaritan Cemeteries and Tombs in the Central Coastal Plain, Archaeology and History of the Samaritan Settlement outside Samaria (ca.300-700). Münster: Ugarit-Verlag.

Uboldi, M. 1995: 'Diffusione delle lampade vitree in Età tardoantica e altomedievale e apunti per una tipologia', Archeol. Mediev. 22: 93-145.

Vessberg, O. 1952: ‘Roman Glass in Cyprus’, OpArch 7: 109-165.

von Schick, B. 1893: 'Letters from Herr Baurath von Schick', PEFQ (October 1893): 282-299.

Weinberg, G. D. \& Stern, E. M. 2009: The Athenian Agora Volume 34: Vessel Glass. Princeton: American School of Classical Studies at Athens.

Whitehouse, D. 1997: Roman Glass in the Corning Museum of Glass. Vol. 1. Corning: Corning Museum of Glass.

Whitehouse, D. 2001: Roman Glass in the Corning Museum of Glass. Vol. 2. Corning: Corning Museum of Glass. 